\title{
The Production of Amyloid $\beta$ Peptide Is a Critical Requirement for the Viability of Central Neurons
}

\author{
Leigh D. Plant, ${ }^{1}$ John P. Boyle, ${ }^{2}$ Ian F. Smith, ${ }^{2}$ Chris Peers, ${ }^{2}$ and Hugh A. Pearson ${ }^{1}$ \\ ${ }^{1}$ Schools of Biomedical Sciences and ${ }^{2}$ Institute for Cardiovascular Research, University of Leeds, Leeds LS2 9JT, United Kingdom
}

The amyloid $\beta$ peptide $(\mathrm{A} \beta)$ is a product of the sequential $\gamma$ - and $\beta$-secretase cleavage of amyloid precursor protein. Inhibitors of secretase enzymes have been proposed as a potential therapeutic strategy in the treatment of Alzheimer's disease. Here, we investigate the effect of inhibiting these key enzymes on the viability of a range of cell types.

Treatment of rat cortical neurons for $24 \mathrm{hr}$ with secretase inhibitors or an antibody that binds $\mathrm{A} \beta$ resulted in a marked reduction in cell viability, as measured by MTT reduction. Incubation with secretase inhibitors caused similar effects on other neuronal cell types (rat cerebellar granule neurons and the human SH-SY5Y cell line). Interestingly, rat astrocytes and a number of non-neuronal cell lines investigated (HEK293, DDT1-FM2, and human teratorhabdoid tumor cells) were unaffected by incubation with secretase inhibitors.

The coincubation of $\mathrm{A} \beta_{1-40}$ prevented the toxicity of secretase inhibitors in neuronal cells. $A \beta_{1-40}$ was protective in a concentrationdependent manner, and its effects were significant at concentrations as low at $10 \mathrm{pm}$. Importantly, the protective effects of $\mathrm{A} \beta$ were $\mathrm{A} \beta$ size-form specific, with the $\mathrm{A} \beta_{1-42}$ size form affording limited protection and the $\mathrm{A} \beta_{25-35}$ size form having very little protective effect.

The present study demonstrates that inhibition of $\beta$ - or $\gamma$-secretase activity induces death in neuronal cells. Importantly, this toxicity, which our data suggest is a consequence of a decline in neuronal $\mathrm{A} \beta$ levels, was absent in non-neuronal cells. This study further supports a key physiological role for the enigmatic $\mathrm{A} \beta$ peptide.

Key words: Alzheimer’s disease; amyloid; secretase; inhibitor; nerve; cell death; physiology

\section{Introduction}

Alzheimer's disease (AD) is characterized pathologically by progressive neurodegeneration and the deposition of aggregated amyloid $\beta$ peptide $(\mathrm{A} \beta)$ as senile plaques. Although the mechanism underlying neurodegeneration remains unclear, a growing body of evidence implicates $\mathrm{A} \beta$ in a pivotal role (Selkoe, 2001). $A \beta$ is derived from the highly regulated and sequential cleavage of amyloid precursor protein (APP) by proteases designated $\beta$-secretase and $\gamma$-secretase. The $\mathrm{A} \beta$ peptide is readily detected in human CSF as a range of isoforms between 38 and 43 amino acids in length, the predominant isoforms being $\mathrm{A} \beta_{1-40}(90 \%)$ and the fibrilogenic $\mathrm{A} \beta_{1-42}$ isoform (10\%). In patients with Alzheimer's disease, the relative proportions of $1-40$ and 1-42 change to $\sim 50 \%$ each (Mehta et al., 2001). Furthermore, the total A $\beta$ burden in brain is increased dramatically (Cummings and Cotman, 1995). Many drug development strategies for potential therapies in $\mathrm{AD}$ therefore focus on reducing this $\mathrm{A} \beta$ load. One such approach identifies the $\beta$ - and $\gamma$-secretases as drug targets. Targeting these secretases may, however, have unforeseen effects because a physiological role for $\mathrm{A} \beta$ has been proposed (Ramsden et al., 2001). With this in mind, we studied the effects of $\beta$ - and $\gamma$-secretase inhibition on the viability of central neurons. We

\footnotetext{
Received Sept. 9, 2002; revised April 30, 2003; accepted March 7, 2003.

We gratefully acknowledge the assistance of the Medical Research Council, the Wellcome Trust, and Pfizer Central Research in supporting this work.

Correspondence should be addressed to Dr. H. A. Pearson, School of Biomedical Sciences, University of Leeds, Leeds LS2 9JT, UK. E-mail: h.a.pearson@leeds.ac.uk.

Copyright $\odot 2003$ Society for Neuroscience $\quad$ 0270-6474/03/235531-05\$15.00/0
}

report evidence suggesting that loss of endogenous $A \beta$ by the pharmacological inhibition of amyloidogenesis results in a severe reduction in the viability of central neurons.

\section{Materials and Methods}

Inhibitors of $\gamma$ - and $\beta$-secretase were purchased from Calbiochem (Nottingham, UK) and dissolved in dimethylsulfoxide and $\mathrm{H}_{2} \mathrm{O}$, respectively. $\mathrm{A} \beta_{1-40}$ was a gift from GlaxoSmithKline Research (Stevenage, UK). $\mathrm{A} \beta_{1-42}$ was purchased from Bachem (St. Helens, UK), and $\mathrm{A} \beta_{25-35}$ was purchased from Sigma (Poole, UK). 3D6 antibody was the kind gift from Elan Pharmaceuticals (San Francisco, CA). Peptides were solubilized in dimethylsulfoxide and dissolved in deoxygenated, deionized $\mathrm{H}_{2} \mathrm{O}$ at 100 $\mu \mathrm{M}$, aliquoted to $10 \mu \mathrm{l}$, and stored at $-20^{\circ} \mathrm{C}$.

Cell culture. Primary cultures of cortical neurons were obtained from 16- to 18-d-old fetal Wistar rat neocortex by enzymatic and mechanical dissociation (MacManus et al., 2000). Cells were grown in 24-well plates in a humidified atmosphere containing $5 \% \mathrm{CO}_{2}$ and $95 \%$ air at $37^{\circ} \mathrm{C}$. Culture medium comprised minimal essential medium (MEM) supplemented with $10 \%$ fetal bovine serum (FBS), $19 \mathrm{~mm} \mathrm{KCl,} 2 \mathrm{~mm}$ L-glutamine, $26 \mathrm{~mm}$ glucose, $50 \mathrm{U} / \mathrm{ml}$ penicillin, and $50 \mu \mathrm{g} / \mathrm{ml}$ streptomycin. After $48 \mathrm{hr}, 80 \mathrm{~mm}$ fluorodeoxyuridine was included in the culture medium to prevent proliferation of non-neuronal cells. The culture medium was exchanged every $3 \mathrm{~d}$, and cells were used in experiments between days 5 and 8 in vitro. Primary cultures of rat cerebellar granule neurons (CGNs) and primary cultures of rat astrocytes, obtained from 6to 8-d-old Wistar rats, were prepared and grown in the same manner as detailed by Plant et al. (2002a). Cells were used in experiments between days 7 and 12 in vitro.

Cell lines (DDT1-FM2, HEK293, and teratorhabdoid tumor cells) were cultured using established methods (Shukla et al., 2001; Plant et al., $2002 \mathrm{~b}$ ) as continuous monolayer cultures in $5 \% \mathrm{CO}_{2}-95 \%$ air at $37^{\circ} \mathrm{C}$. 
Medium consisted of 50\% MEM with Earle's salts and L-glutamine and 50\% F-12 neuronal supplement. Media were supplemented with $10 \%$ FBS, $1 \%$ non-essential amino acids, penicillin $(50 \mathrm{U} / \mathrm{ml})$, and streptomycin and gentamicin (both at $50 \mu \mathrm{g} / \mathrm{ml}$ ).

3-(4,5-Dimethylthiazol-2-yl)-2,5-

diphenyltetrazolium bromide assay. Cell viability was assessed using the 3-(4,5-dimethylthiazol-2-yl)-2,5-diphenyltetrazolium bromide (MTT) reduction assay (Mosmann, 1983) as described previously (Ramsden et al., 2001; Shukla et al., 2001). Absorbency was measured using a spectrophotometer at a test wavelength of $570 \mathrm{~nm}$ and reference wavelength of $630 \mathrm{~nm}$. Student's $t$ test (unpaired) was used to determine the significance of differences between means, with $p$ values $<0.05$ being considered significant.

Immunocytochemistry. For immunocytochemical experiments, cells were washed with PBS before being fixed with paraformaldehyde (4\% in PBS) for $20 \mathrm{~min}$. After a second wash step, cells were permeabilized using PBS containing $0.2 \%$ Triton X-100 and $10 \%$ normal goat serum (NGS). Cells were then washed with PBS containing $1 \%$ NGS before being incubated overnight with a monoclonal antibody $(1: 1000)$ raised against the first five $\mathrm{N}$-terminal amino acids of $\mathrm{A} \beta$ (3D6), prepared in PBS containing $1 \%$ NGS. The secondary antibody was added in PBS containing $1 \%$ NGS for $1 \mathrm{hr}$ after a series of PBS washes. Secondary antibody was a donkey anti-rabbit conjugated with a Cy3 fluorescent label (1:1000; Jackson ImmunoResearch, West Grove, PA). Coverslips were mounted onto microscope slides using 50\% glycerol in PBS and sealed using standard nail lacquer. Slides were stored at $4^{\circ} \mathrm{C}$ in the dark until used. Cells were viewed using a Zeiss (Oberkochen, Germany) Axioscop epifluorescence microscope fitted with a rhodamine filter set. Images were captured using a CCD camera and AcQuis image acquisition software (Synchroscopy, Cambridge, UK). All images were acquired using identical exposures and settings.

\section{Results \\ Inhibition of $\gamma$-secretase induces morphological changes in cortical neurons}

$\gamma$-Secretase activity is mediated by a multi-enzyme complex containing presenilin and nicastrin and represents the rate-limiting step in amyloidogenisis (Kaether et al., 2002). The enzymatic activity of this complex is sensitive to the peptide aldehyde 2 -naphthoyl-VF-CHO $(\gamma$-IV). $\gamma$-IV is cell permeable and has been shown to reversibly inhibit both $\mathrm{A} \beta_{1-40}$ and $\mathrm{A} \beta_{1-42}$ production with $\mathrm{ED}_{50}$ values of 2.6 and $2.7 \mu \mathrm{M}$, respectively (Sinha and Lieberburg, 1999). We treated primary cultures of rat neocortical neurons with $10 \mu \mathrm{M} \gamma$-IV for $24 \mathrm{hr}$ and noted marked changes in the appearance of these cells. Application of $\gamma$-IV induced cell shrinkage, granularization, and an apparent reduction in neuronal cell number (Fig. 1).

Because the turnover of $A \beta$ is reported to be as rapid as $2 \mathrm{hr}$ in central neurons (Savage et al., 1998), we hypothesized that preventing de novo amyloidogenesis and allowing endogenous $\mathrm{A} \beta$ levels to decline could underlie the apparent toxicity of chronic $\gamma$-IV treatment. To test this hypothesis, we coincubated neocortical neurons with $\gamma$-IV and $1 \mathrm{~nm} \mathrm{~A} \beta_{1-40}$ for $24 \mathrm{hr}$. This strategy precluded the apparent toxicity of $\gamma$-IV treatment and suggests that a decrease in $\mathrm{A} \beta$ levels underlies this effect (Fig. 1C).

\section{Secretase inhibition is associated with decreased cell viability} The MTT assay was used to quantify the relative viability of neocortical pyramidal neurons after chronic $\gamma$-IV treatment. This colorimetric assay corroborated our morphological study. Thus,
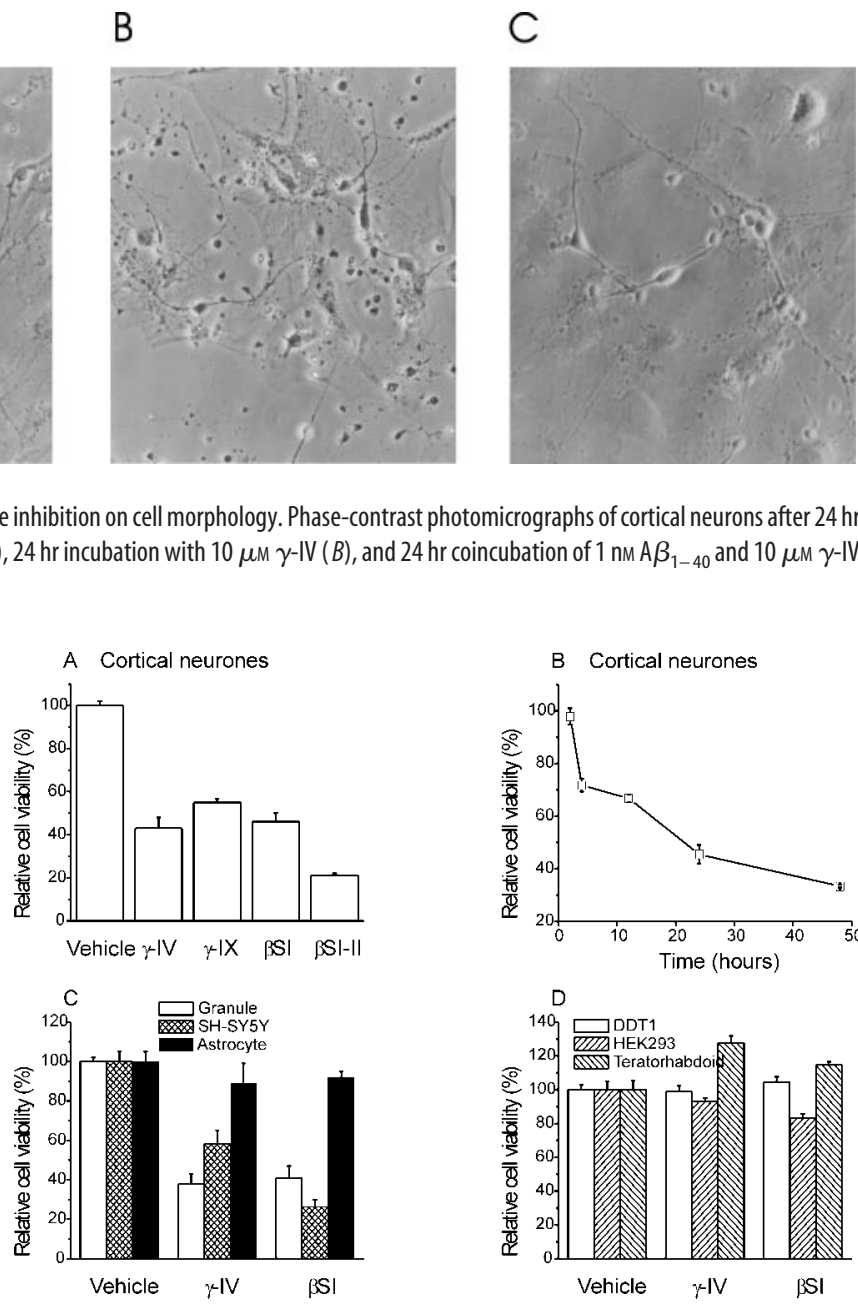

Figure 2. Effect of secretase inhibition on cell viability. $A$, Incubation for $24 \mathrm{hr}$ with $\gamma$ - or $\beta$-secretase inhibitors on the viability of cortical neurons ( $n=9$ for each condition). $B$, Time dependence of $\gamma$-IV toxicity on cortical cultures compared with vehicle-treated controls. Values are the mean of four experiments for each time point. C, Effect of $24 \mathrm{hr}$ incubation with secretase inhibitors on cell death in cerebellar granule neurons (open bars; $n=9$ ), the SH-SY5Y cell line (hatched bars; $n=9$ ), and rat astrocytes cultures (filled bars; $n=9$ ). $D$, Effect of 48 hr incubation with secretase inhibitors on the viability of non-neuronal cell lines DDT1-FM2 (open bars; $n=4$ ), HEK293 (hatched bars; $n=4$ ), and human teratorhabdoid tumor cells (filled bars; $n=4) . \gamma-\mathrm{IX}, \gamma$-secretase inhibitor.

a $24 \mathrm{hr}$ treatment with $\gamma$-IV decreased relative viability of neocortical neurons to $43 \pm 5 \%(n=9 ; p<0.05)$ compared with untreated cells (Fig. 2A). A second inhibitor of $\gamma$-secretase, $N$-[N-(3,5-difluorophenacetyl-L-alanyl) $]$-S-phenylglycine $t$-butyl ester, designated $\gamma$-secretase inhibitor IX (200 nM) was similarly effective in reducing cortical cell survival (Fig. $2 A$ ).

$\gamma$-Secretase activity is implicated in a number of neuronal pathways, including Notch processing (Selkoe, 2001). It was crucial to determine the relative importance of amyloidogenisis in contributing to the toxicity of $\gamma$-secretase inhibition and exclude the possibility that other pathways might mediate this effect. To resolve this issue, we sought to prevent $\mathrm{A} \beta$ production by a second method. H-KTEEISEVN-stat-VAEF-OH ( $\beta$ SI) is a potent inhibitor of $\beta$-secretase activity ( $\mathrm{IC}_{50}$ of $30 \mathrm{nM}$ ) (Sinha et al., $1999)$, preventing the initial cleavage of APP and therefore, subsequent $\mathrm{A} \beta$ production. A $24 \mathrm{hr}$ treatment with $\beta S \mathrm{I}$ (100 nM) mimicked the decrease in relative cell viability measured in these neurons after treatment with $\gamma$-secretase inhibitor $(p<0.05)$ 


\section{A Control}

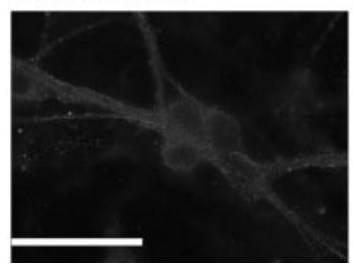

C $ß S I$

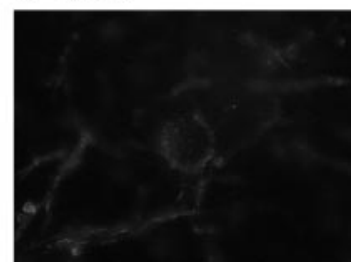

Figure 3. Effect of secretase inhibition on $A \beta$ levels in neurons. Fluorescence photomicrographs of cerebellar granule neurons under control conditions $(A)$, after $24 \mathrm{hr}$ incubation with $10 \mu \mathrm{m} \gamma$-IV $(B)$, and after $24 \mathrm{hr}$ incubation with $100 \mathrm{~nm} \beta S \mathrm{SI}(C)$. Scale bar, $30 \mu \mathrm{m}$.
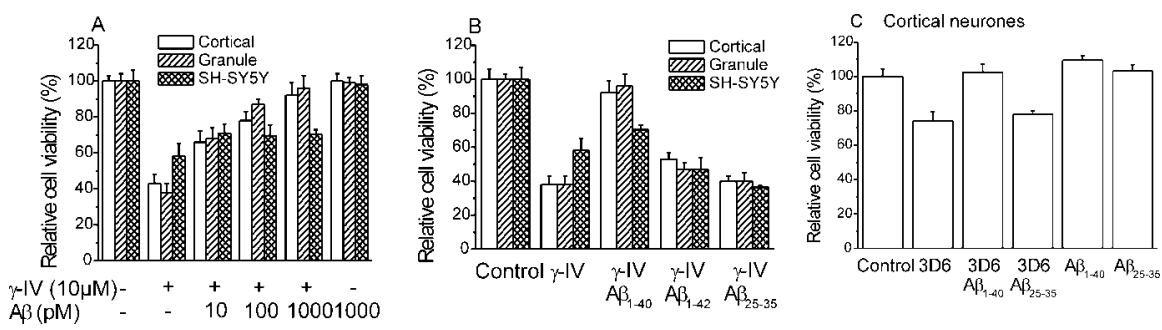

Figure 4. Effect of amyloid proteins on $\gamma$-secretase inhibitor neurotoxicity. $A$, Effect of $24 \mathrm{hr}$ incubation with $\gamma$-secretase inhibitor on the viability of cortical neurons (open bars; $n=9$ ), cerebellar granule neurons (striped bars; $n=9$ ), and the SH-SY5Y cell line (hatched bars; $n=9$ ) in the presence of different concentrations of $A \beta_{1-40} . B$, Effect of $24 \mathrm{hr}$ incubation with $\gamma$-secretase inhibitor $(10 \mu \mathrm{m}$ ) on the viability of cortical neurons (open bars; $n=9$ ), cerebellar granule neurons (striped bars; $n=9$ ), and the SH-SY5Y cell line (hatched bars; $n=9$ ) in the presence of different A $\beta$ size forms at a concentration of $1 \mathrm{~nm}$ in each case. $C$, Toxicity of the monoclonal antibody $3 \mathrm{D} 6(1 \mu \mathrm{g} / \mathrm{ml}, 24 \mathrm{hr})$ on cortical neurons. Toxicity was reversed by coincubation with $\mathrm{A} \beta_{1-40}(1 \mathrm{~nm})$ but not $A \beta_{25-35}(1 \mathrm{~nm})$. $A \beta$ peptides alone had no effect on cell survival. In each case, $n=4$.

(Fig. 2A). A second inhibitor of $\beta$-secretase, $N$-bennzyloxycarbonyl-valine-leucine-leucinal ( $\beta$ SI-II) $(10 \mu \mathrm{M})$ (Abbenante et al., 2000), was also highly effective in compromising cell survival (Fig. 2A).

The ability of $\gamma$-IV to kill cells was time dependent. Figure $2 B$ shows the effect of incubating cortical cultures with $10 \mu \mathrm{M} \gamma$-IV for periods of $2-48 \mathrm{hr}$. Significant inhibition $(n=4 ; p<0.05)$ of viability occurred within $4 \mathrm{hr}$ of the initial application of $\gamma$-IV, and additional increases in toxicity were observed over the full time course examined.

\section{Secretase inhibitors are toxic to neurons but not to non-neuronal cells}

To assess the impact of secretase inhibition on other cell types, we corroborated our investigation with primary cultures of rat CGNs and the human neuroblastoma cell line SH-SY5Y. The MTT assay revealed the marked toxic effects of both $\gamma$-IV and $\beta$ SI in both cell types. After $24 \mathrm{hr}$ (Fig. 2C) and $48 \mathrm{hr}$ (data not shown) treatment, cell viabilities were reduced to a similar extent to that seen in the cortical neurons. Interestingly, primary cultured rat astrocytes taken from the cerebral cortices of the same animals used to produce cerebellar granule cultures were primarily unaffected by secretase inhibition (Fig. 2C) (see also background astrocytes in Fig. 1). This suggests that the toxic effects of secretase inhibitors are neuron specific. To test this further, we applied secretase inhibitors to a variety of non-neuronal cell types. These were the hamster smooth muscle cell line DDT1-FM2, the human embryonic kidney cell line HEK293, and a primary culture of cells isolated from a human teratorhabdoid tumor. No clear induction of cell death was observed in any of these non-neuronal cell types in response to incubation with either $\gamma$-IV or $\beta$ SI for up to $48 \mathrm{hr}$ (Fig. 2D).

We used an immunocytochemical approach to show that the secretase inhibitors were effective in reducing $A \beta$ production under the conditions used in our experiments. Figure 3 shows the effect of $\gamma$-IV and $\beta$ SI on endogenous $\mathrm{A} \beta$ immunostaining in cerebellar granule neurons. Under control conditions, a dense, punctate staining could be observed in the cytoplasm and membrane of cells (Fig. 3A). This staining was greatly reduced in cells that had been treated with either $\gamma$-IV or $\beta$ SI for $24 \mathrm{hr}$ (Fig. $3 \mathrm{~B}, \mathrm{C}$ ). Thus, a clear and substantial reduction in endogenous $A \beta$ levels was effected by the application of these inhibitors.

\section{Cell death induced by secretase inhibitors is dependent on $\mathrm{A} \boldsymbol{\beta}$ production}

The independent inhibition of two distinct enzymes in distinct neuronal populations provides evidence that amyloidogenesis plays an integral role in determining the viability of central neurons grown in culture. To prove the importance of $A \beta$ to this system, we attempted to recover the deficit in relative cell viability associated with secretase inhibition by the addition of exogenous $\mathrm{A} \beta$. In previous studies, we demonstrated that the incubation of primary cultures of rat neurons with the physiologically prevalent $\mathrm{A} \beta_{1-40}$ isoform, at concentrations as high as $1 \mu \mathrm{M}$, is not associated with a reduction in relative cell viability (Ramsden et al. 2001). We coincubated cells with either $\gamma$-IV or $\beta$ SI and a number of different $A \beta$ size forms at a range of concentrations for $24 \mathrm{hr}$. Concentrations of $\mathrm{A} \beta$ in the range of $10 \mathrm{pM}$ to $1 \mathrm{nM}$ were effective in reversing the toxic effect of $\gamma$-secretase inhibition (Fig. $4 A$ ). Indeed, 10 рм A $\beta$ afforded significant rescue of $\gamma$-IV-induced cell death in both cortical and cerebellar granule cell cultures $(n=9$ in each case; $p<0.05)$. Such concentrations are within the range reported from measurements of $\mathrm{A} \beta$ concentrations in human CSF (Mehta et al., 2001), suggesting that this is a physiological effect. A $\beta$ was less effective in reversing the toxicity of secretase inhibitors in SH-SY5Y. However, at higher concentrations, the effectiveness of $\mathrm{A} \beta$ became evident. For instance, when cells were coincubated with $10 \mathrm{~nm} \mathrm{~A} \beta$ and $10 \mu \mathrm{M} \gamma$-IV, cell viability was $69 \pm 3 \%(n=6)$ compared with $58 \pm 7 \%(n=8)$ in the presence of $\gamma$-IV alone. Increasing the $\mathrm{A} \beta$ concentration further to $100 \mathrm{nM}$ or $1 \mu \mathrm{M}$ increased viability to $80 \pm$ $6 \%(n=4)$ and $83 \pm 9 \%(n=4)$, respectively.

Importantly, the ability of $\mathrm{A} \beta$ to recover cell death in cortical neurons treated with $\gamma$ - or $\beta$-secretase inhibitors was dependent on the species of $\mathrm{A} \beta$ used. $\mathrm{A} \beta_{1-42}$ represents $\sim 10 \%$ of total amyloid detected in human CSF. Coincubation of $\gamma$-IV or $\beta$ SI with 1 $\mathrm{nM} \mathrm{A} \beta_{1-42}$ resulted in partial rescue of the cell death associated with secretase inhibitors in cortical neurons and granule cells (Fig. $4 B$ ). This isoform of $\mathrm{A} \beta$ had no ability to recover cell death in SH-SY5Y cells at $1 \mathrm{~nm}$ (Fig. $4 B$ ) or at concentrations up to $1 \mu \mathrm{M}$ (data not shown). In addition, the synthetic toxic portion of $A \beta$, $\mathrm{A} \beta_{25-35}(1 \mathrm{nM})$ (Kowall et al., 1992), failed to rescue the deficit in cortical or granule neuron viability associated with either secretase inhibitor (Fig. $4 B$ ).

Additional evidence showing that endogenous $\mathrm{A} \beta$ production is essential for the survival of neurons is provided by experiments in which $\mathrm{A} \beta$ was bound by the application of the $\mathrm{A} \beta$-binding 
antibody 3D6. Incubation of cortical neuron cultures with 3D6 (1 $\mu \mathrm{g} / \mathrm{ml}$ ) for $24 \mathrm{hr}$ resulted in a significant reduction in cell viability (Fig. $4 C$ ). This was an effect specific to the $\mathrm{A} \beta$-binding properties of the antibody because coincubation with $\mathrm{A} \beta_{1-40}$, but not $\mathrm{A} \beta_{25-35}$, was effective in reversing the toxic effect of 3D6.

\section{Discussion}

The data presented here indicate that inhibition of $\beta$ - or $\gamma$-secretase in neurons can compromise cell viability. In three different neuronal phenotypes, the pharmacological knockdown of amyloidogenic secretase activity resulted in cell death.

Is the toxicity of these compounds attributable to inhibition of $\mathrm{A} \beta$ production? There are several lines of evidence that suggest this to be the case. First, these compounds have been shown to produce a profound inhibition of $\mathrm{A} \beta$ production at the concentrations used in this study. Greater than $99 \%$ inhibition of de novo $\mathrm{A} \beta$ production would be expected at $\gamma$-IV concentrations used here (Beher et al., 2001), and our own immunocytochemical data would appear to confirm this. Second, the production of $A \beta$ has been prevented in two ways via the pharmacological inhibition of two distinct and separate enzymes. Importantly, all compounds used were structurally different, suggesting that toxicity was not the nonspecific result of a particular chemical moiety. Third, in experiments using the 3D6 antibody to bind and neutralize $\mathrm{A} \beta$, we observed a toxic effect. This approach has been used previously to prevent some of the effects mediated by $\mathrm{A} \beta$ during hypoxia (Green and Peers, 2001). Significantly, we were again able to prevent the toxic effect of the antibody by coincubation with exogenously added $\mathrm{A} \beta$. All of these data suggest that the toxicity induced by secretase inhibitors in cells with a neuronal phenotype is not simply a chemical toxicity but is related to an interaction with neuron-specific pathways, such as $\mathrm{A} \beta$ production. Finally, the lack of toxicity in non-neuronal cell types argues strongly against a nonspecific toxicity for these compounds.

The notion that toxicity is a result of inhibition of physiological $A \beta$ production is given additional weight by evidence that the replacement of endogenous $\mathrm{A} \beta$ with picomolar concentrations of exogenous $A \beta$ recovers cell viability. Importantly, the rescue of cell death by $\mathrm{A} \beta$ is dependent on the species of this peptide used. This effect is most pronounced when the physiologically prevalent $\mathrm{A} \beta$ species $1-40$ is used. $A \beta_{1-40}$ demonstrated rescue of toxicity in a concentration-dependent manner and is effective in recovering total cell viability to control levels at concentrations between $10 \mathrm{pm}$ and $1 \mathrm{nM}$. This concentration range corresponds with that reported from human CSF (Mehta et al., 2001). Notably, $\mathrm{A} \beta_{1-42}$, which is present at much lower concentrations in human CSF, is less efficient in rescuing neuronal cell viability. This may represent a lesser physiological requirement for $\mathrm{A} \beta_{1-42}$, a distinct protein that may be unable to fulfil $A \beta_{1-40}$-specific roles. An additional possibility is that $\mathrm{A} \beta_{1-42}$ levels are not diminished as rapidly as $A \beta_{1-40}$ levels after secretase inhibition. This is supported by recent studies in which $\mathrm{A} \beta_{1-42}$ production was demonstrated in cells deficient for both presenilin 1 (PS1) and PS2, the likely locus of $\gamma$-secretase inhibitor activity (Wilson et al., 2002). However, the effects of $\beta$-secretase inhibitors in our study argue against this possibility. In marked contrast to the protective effect of $A \beta_{1-40}$, the 25-35 amino acid sequence of $A \beta$ afforded no rescue to neuronal cells treated with inhibitors of either $\beta$ - or $\gamma$-secretase. This synthetic peptide does not exist naturally in either healthy individuals or Alzheimer's pathology. It is therefore not surprising that $A \beta_{25-35}$ appears to be unable to substitute for endogenous $A \beta$ in preventing secretase inhibitor toxicity.
Pharmacological inhibitors of $\beta$ - or $\gamma$-secretase activities are being developed at a prodigious rate. The question arises therefore of why this overt neurotoxicity has not been reported previously. Many studies explore the pharmacology of these compounds via cell-free processing often in terms of the enzymatic activity of $\beta$ - and $\gamma$-secretases (Sinha et al., 1999). In vitro studies predominantly use a range of non-neuronal cell lines that have been transformed to overexpress amyloid precursor protein (Sinha and Lieberburg, 1999). Because the data presented here suggests that these cells do not rely on $\mathrm{A} \beta$ production for viability, the toxicity of the secretase inhibitors would not have been observed. Studies using neuronal cells have only examined the efficacies of secretase inhibitors over short incubation times (Beher et al., 2001). Allusions have been made to the toxicity of secretase inhibitors, restricting the concentrations of, for example, $\gamma$-IV that are suitable to explore $\gamma$-secretase-dependent behavior in embryonic stem cells, although this toxicity was not further investigated (Wilson et al., 2002).

The effects of reduced secretase activity have also been investigated using knock-out mice. $\beta$-Secretase activity is mediated by BACE, or $\beta$-site APP cleavage enzyme (Vassar and Citron, 2000). BACE-1 knock-out mice have been used to probe the functional importance of this enzyme and were found to have a normal phenotype for up to 1 year with a reduced $\mathrm{A} \beta$ production (Roberds et al., 2001). This might be taken to suggest that BACE-1 does not participate in the generation of physiologically important proteins (Cai et al., 2001; Luo et al., 2001). Constitutive knock-down of the activity of a single enzyme often leads to compensatory mechanisms in genetically manipulated organisms. Compensation for this deficit by BACE- 2 and as yet unidentified enzymes is a possible explanation for this anomaly. Additional inhibition of BACE-2 activity would aid our understanding of the physiological relevance of $\beta$-secretase activity.

In contrast to BACE, a double-genetic knock-out of presenilin 1 and 2 activity proved to be fatal in utero (Herreman et al., 1999). This toxicity is primarily a result of inhibition of Notch signaling (De Strooper et al., 1999), and inhibition of Notch was suggested at the time to be a possible source of $\gamma$-secretase inhibitor toxicity. Knock-out of PS1 alone does not have a toxic effect, although A $\beta$ production is reduced by $80 \%$ in cells cultured from such animals (De Strooper et al., 1998; Annaert et al., 2001). Thus, the physiological role of $\mathrm{A} \beta$ remains unconfirmed using such models.

An alternative to secretase knock-out is the knock-out of APP. This appears to cause mild neurological and behavioral deficits in homozygous animals (Zheng et al., 1995). Neurons from such animals can be readily grown in culture (Harper et al., 1998; White et al., 1998), suggesting that APP and its cleavage products are not required for cell survival. However, recent studies have revealed that cleavage products of the closely related APP-like proteins (APPLP1 and APPLP2) have a role as transcriptional regulators (Scheinfeld et al., 2002) and can substitute for APP itself. A combined APP/APPLP knock-out displays growth retardation and early postnatal lethality attributable to an unknown cause, supporting the hypothesis that the APP/APPLP family and their products have important physiological functions (Heber et al., 2000).

In conclusion, we showed that, in rodent and human neuronal cell types, in vitro inhibition of $\gamma$ - or $\beta$-secretase production of $A \beta$ and binding and neutralization of $A \beta$ with an antibody leads to toxicity. Recovery of cell viability by the addition of physiologically relevant concentrations of $A \beta$ suggest that this peptide 
may have a role to play in the normal function of neuronal cells as suggested previously (Ramsden et al., 2001).

\section{References}

Abbenante G, Kovacs DM, Leung DL, Craik DJ, Tanzi RE, Fairlie DP (2000) Inhibitors of beta-amyloid formation based on the beta-secretase cleavage site. Biochem Biophys Res Commun 268:133-135.

Annaert WG, Esselens C, Baert V, Boeve C, Snellings G, Cupers P, Craessaerts K and De Strooper B (2001) Interaction with telencephalin and the amyloid precursor protein predicts a ring structure for presenilins. Neuron 32:579-589.

Beher D, Wrigley JD, Nadin A, Evin G, Masters CL, Harrison T, Castro JL, Shearman MS (2001) Pharmacological knock-down of the presenilin 1 heterodimer by a novel gamma-secretase inhibitor: implications for presenilin biology. J Biol Chem 276:45394-45402.

Cai H, Wang Y, McCarthy D, Wen H, Borchelt DR, Price DL, Wong PC (2001) BACE1 is the major beta-secretase for generation of $A \beta$ peptides by neurons. Nat Neurosci 4:233-234.

Cummings BJ, Cotman CW (1995) Image analysis of beta-amyloid load in Alzheimer's disease and relation to dementia severity. Lancet 346:1524-1528.

De Strooper B, Saftig P, Craessaerts K, Vanderstichele H, Guhde G, Annaert W, Von Figura K, Van Leuven F (1998) Deficiency of presenilin-1 inhibits the normal cleavage of amyloid precursor protein. Nature 391:387-390.

De Strooper B, Annaert W, Cupers P, Saftig P, Craessaerts K, Mumm JS, Schroeter EH, Schrijvers V, Wolfe MS, Ray WJ, Goate A, Kopan R (1999) A presenilin-1-dependent gamma-secretase-like protease mediates release of Notch intracellular domain. Nature 398:518-522.

Green KN, Peers C (2001) Amyloid beta peptides mediate hypoxic augmentation of $\mathrm{Ca}^{2+}$ channels. J Neurochem 77:953-956.

Harper SJ, Bilsland JG, Shearman MS, Zheng H, Van der Ploeg L, Sirinathsinghji DJ (1998) Mouse cortical neurones lacking APP show normal neurite outgrowth and survival responses in vitro. NeuroReport 9:3053-3058.

Heber S, Herms J, Gajic V, Hainfellner J, Aguzzi A, Rulicke T, von Kretzschmar H, von Koch C, Sisodia S, Tremml P, Lipp HP, Wolfer DP, Muller U (2000) Mice with combined gene knock-outs reveal essential and partially redundant functions of amyloid precursor protein family members. J Neurosci 20:7951-7963.

Herreman A, Hartmann D, Annaert W, Saftig P, Craessaerts K, Serneels L, Umans L, Schrijvers V, Checler F, Vanderstichele H, Baekelandt V, Dressel R, Cupers P, Huylebroeck D, Zwijsen A, Van Leuven F, De Strooper B (1999) Presenilin 2 deficiency causes a mild pulmonary phenotype and no changes in amyloid precursor protein processing but enhances the embryonic lethal phenotype of presenilin 1 deficiency. Proc Natl Acad Sci USA 96:11872-11877.

Kaether C, Lammich S, Edbauer D, Ertl M, Rietdorf J, Capell A, Steiner H, Haass C (2002) Presenilin-1 affects trafficking and processing of $\{$ beta\}APP and is targeted in a complex with nicastrin to the plasma membrane. J Cell Biol 158:551-561.

Kowall NW, McKee AC, Yankner BA, Beal MF (1992) In vivo neurotoxicity of beta-amyloid [beta(1-40)] and the beta(25-35) fragment. Neurobiol Aging 13:537-542.

Luo Y, Bolon B, Kahn S, Bennett BD, Babu-Khan S, Denis P, Fan W, Kha H, Zhang J, Gong Y, Martin L, Louis JC, Yan Q, Richards WG, Citron M, Vassar R (2001) Mice deficient in BACE1, the Alzheimer's betasecretase, have normal phenotype and abolished beta-amyloid generation. Nat Neurosci 4:231-232.
MacManus A, Ramsden M, Murray M, Henderson Z, Pearson HA, Campbell VA (2000) Enhancement of (45) $\mathrm{Ca}^{2+}$ influx and voltage-dependent $\mathrm{Ca}^{2+}$ channel activity by beta-amyloid-(1-40) in rat cortical synaptosomes and cultured cortical neurons. Modulation by the proinflammatory cytokine interleukin-1beta. J Biol Chem 275:4713-4718.

Mehta PD, Pirttila T, Patrick BA, Barshatzky M, Mehta SP (2001) Amyloid beta protein 1-40 and 1-42 levels in matched cerebrospinal fluid and plasma from patients with Alzheimer disease. Neurosci Lett 304:102-106.

Mosmann T (1983) Rapid colorimetric assay for cellular growth and survival: application to proliferation and cytotoxicity assays. J Immunol Methods 65:55-63.

Plant LD, Kemp PJ, Peers C, Henderson Z, Pearson HA (2002a) Hypoxic depolarization of cerebellar granule neurones by specific inhibition of TASK-1. Stroke 33:2324-2328.

Plant LD, Boyle JP, Thomas NM, Hipkins NJ, Benediks E, Hooper NM, Henderson Z, Peers C, Cowburn RF, Pearson HA (2002b) Presenilin-1 mutations alter $\mathrm{K}^{+}$currents in the human neuroblastoma cell line, $\mathrm{SH}-$ SY5Y. NeuroReport 13:1553-1556.

Ramsden M, Plant LD, Webster NJ, Vaughan PFT, Henderson Z, Pearson HA (2001) Differential effects of unaggregated and aggregated amyloid $\beta$ protein (1-40) on $\mathrm{K}^{+}$channel currents in primary cultures of rat cerebellar granule and cortical neurones. J Neurochem 79:699-712.

Roberds SL, Anderson J, Basi G, Bienkowski MJ, Branstetter DG, Chen KS, Freedman SB, Frigon NL, Games D, Hu K, Johnson-Wood K, Kappenman KE, Kawabe TT, Kola I, Kuehn R, Lee M, Liu W, Motter R, Nichols NF, Power M, et al. (2001) BACE knockout mice are healthy despite lacking the primary beta-secretase activity in brain: implications for Alzheimer's disease therapeutics. Hum Mol Genet 10:1317-1324.

Savage MJ, Trusko SP, Howland DS, Pinsker LR, Mistretta S, Reaume AG, Greenberg BD, Siman R, Scott RW (1998) Turnover of amyloid betaprotein in mouse brain and acute reduction of its level by phorbol ester. J Neurosci 18:1743-1752.

Scheinfeld MH, Ghersi E, Laky K, Fowlkes BJ, D’Adamio L (2002) Processing of beta-amyloid precursor-like protein- 1 and -2 by gamma-secretase regulates transcription. J Biol Chem 277:44195-44201.

Selkoe DJ (2001) Clearing the brain's amyloid cobwebs. Neuron 32:177-180.

Shukla C, Plant LD, Finch LH, Grumbridge S, Henderson Z, Bridges LR, Pearson HA (2001) Differential effects of antioxidants on $\mathrm{A} \beta$ and $\mathrm{H}_{2} \mathrm{O}_{2}$ induced cell death in the SH-SY5Y neuronal cell line. J Cell Path 5:241-249.

Sinha S, Lieberburg I (1999) Cellular mechanisms of beta-amyloid production and secretion. Proc Natl Acad Sci USA 96:11049-11053.

Sinha S, Anderson JP, Barbour R, Basi GS, Caccavello R, Doan M, Dovey HF, Frigon N, Hong J, Jacobson-Croak K, Jewett N, Keim P, Knops J, Lieberburg I, Power, Tan H, Tatsuno G, Tung J, Schenk D, Seubert P, et al. (1999) Purification and cloning of amyloid precursor protein betasecretase from human brain. Nature 402:537-540.

Vassar R, Citron M (2000) A $\beta$-generating enzymes: recent advances in $\beta$ and $\gamma$-secretase activity. Neuron 27:419-422.

White AR, Zheng H, Galatis D, Maher F, Hesse L, Multhaup G, Beyreuther K, Masters CL, Cappai R (1998) Survival of cultured neurons from amyloid precursor protein knock-out mice against Alzheimer's amyloid- $\beta$ toxicity and oxidative stress. J Neurosci 18:6207-6217.

Wilson CA, Doms RW, Zheng H, Lee VM (2002) Presenilins are not required for $\mathrm{A} \beta 42$ production in the early secretory pathway. Nat. Neurosci 5:849-855.

Zheng H, Jiang M, Trumbauer ME, Sirinathsinghji DJ, Hopkins R, Smith DW, Heavens RP, Dawson GR, Boyce S, Conner MW, Stevens KA, Slunt HH, Sisodia SS, Chen HY, Van Der Ploeg LHT (1995) beta-Amyloid precursor protein-deficient mice show reactive gliosis and decreased locomotor activity. Cell 81:525-531. 